ERNEST ORLANDO LAWRENCE

BERKELEY NATIONAL LABORATORY

\title{
Community Wind: \\ Once Again Pushing the Envelope of Project Finance
}

\author{
Mark Bolinger
}

Environmental Energy Technologies Division

January 2011

Download from http:/leetd.Ibl.gov/EA/EMP/re-pubs.html

The work described in this report was funded by the U.S. Department of Energy's Office of Energy Efficiency and Renewable Energy (Wind \& Water Power Program) under Contract No. DE-AC02-05CH11231. 


\section{Disclaimer}

This document was prepared as an account of work sponsored by the United States Government. While this document is believed to contain correct information, neither the United States Government nor any agency thereof, nor The Regents of the University of California, nor any of their employees, makes any warranty, express or implied, or assumes any legal responsibility for the accuracy, completeness, or usefulness of any information, apparatus, product, or process disclosed, or represents that its use would not infringe privately owned rights. Reference herein to any specific commercial product, process, or service by its trade name, trademark, manufacturer, or otherwise, does not necessarily constitute or imply its endorsement, recommendation, or favoring by the United States Government or any agency thereof, or The Regents of the University of California. The views and opinions of authors expressed herein do not necessarily state or reflect those of the United States Government or any agency thereof, or The Regents of the University of California.

Ernest Orlando Lawrence Berkeley National Laboratory is an equal opportunity employer.

\section{Acknowledgments}

The work described in this report was funded by the U.S. Department of Energy's Office of Energy Efficiency and Renewable Energy (Wind \& Water Power Program) under Contract No. DE-AC02-05CH11231. Thank you to Patrick Gilman of the U.S. Department of Energy for his support of this work. In addition, the author would like to thank the following individuals for providing information and/or reviewing earlier drafts of this manuscript: George Baker (Fox Islands Wind, LLC); Ormand Hilderbrand (Oregon Trail Wind Farm, LLC); Joaquin Altenberg (Vert Investment Group); Nick Sershen (Val-Add Service Corporation); Jeff Nelson (East River Electric Power Cooperative); Paul White (Project Resources Corporation); Alice Orrell (Pacific Northwest National Laboratory); Paul Schwabe (National Renewable Energy Laboratory); Patrick Gilman, Jim Ahlgrimm, and Megan McCluer (U.S. Department of Energy); Jacob Susman (OwnEnergy); Dan Yarano (Fredrikson \& Byron, P.A.); Ed Ing (Law Offices of Edwin T.C. Ing); and Ryan Wiser (LBNL). Of course, any remaining errors or omissions are the sole responsibility of the author. 


\section{Table of Contents}

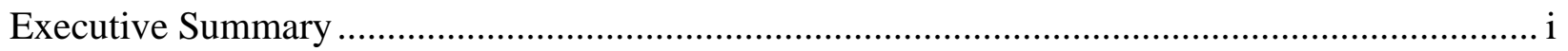

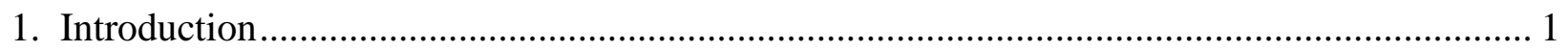

2. How Community Wind Projects Have Traditionally Been Financed......................................... 3

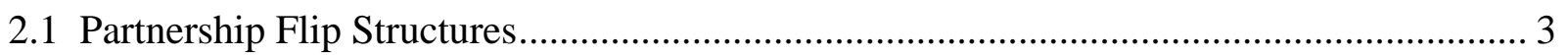

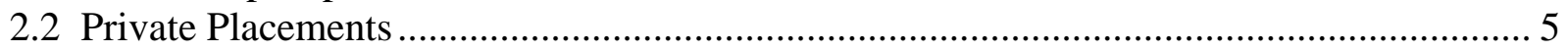

3. Recent Policy Changes Have Facilitated Financial Innovation .................................................. 6

4. Five Recent Projects Exemplify the Breadth of Innovation .................................................... 8

4.1 Fox Islands Wind, LLC............................................................................................ 8

4.2 Ridgewind Power Partners, LLC …………………....................................................... 11

4.3 South Dakota Wind Partners, LLC ............................................................................... 13

4.4 Coastal Energy Project, LLC ……………………..................................................... 17

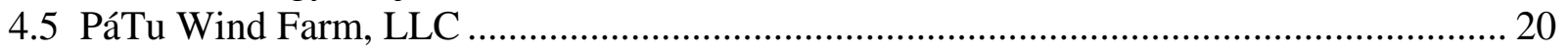

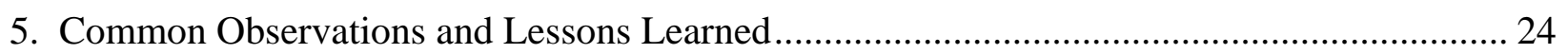

5.1 The Recovery Act Has Been Critically Important to Most of These Projects.................... 24

5.2 Don't Overlook The Need for Seed Capital ..................................................................... 24

5.3 Piggybacking on Nearby Projects Can Help Ease the Burden ............................................ 25

5.4 Partnering With Experienced Professionals Can Create Opportunities............................... 25

5.5 Consider the RUS As a Source of Debt ....................................................................... 25

5.6 Don’t Overlook New Markets Tax Credits..................................................................... 26

5.7 Be Prepared for a Long Haul ............................................................................................. 26

5.8 The Shift from Construction to Commercial Operations Can Bring New Challenges...... 26

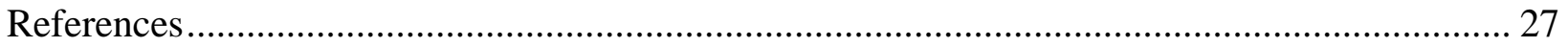




\section{Executive Summary}

The "community wind" sector in the United States - defined in this report as consisting of relatively small utility-scale wind power projects that sell power on the wholesale market and that are developed and owned primarily by local investors - has historically served as a "test bed" or "proving grounds" not only for up-and-coming wind turbine manufacturers trying to break into the broader U.S. wind market, but also for wind project financing structures. For example, a variation of one of the most common financing arrangements in the U.S. wind market today - the special allocation partnership flip structure (as described in Section 2.1 and Figure 1 of the full report) - was first developed by community wind projects in Minnesota more than a decade ago before being adopted by the broader wind market.

More recently, a handful of community wind projects built over the past year have been financed via new and creative structures that push the envelope of wind project finance in the U.S. - in many cases, moving beyond the now-standard partnership flip structures involving strategic tax equity investors. These include:

- a 4.5 MW project in Maine that combines low-cost government debt with local tax equity,

- a 25.3 MW project in Minnesota using a sale/leaseback structure,

- a 10.5 MW project in South Dakota financed by an intrastate offering of both debt and equity,

- a 6 MW project in Washington state that taps into New Markets Tax Credits using an "inverted" or "pass-through" lease structure, and

- a 9 MW project in Oregon that combines a variety of state and federal incentives and loans with unconventional equity from high-net-worth individuals.

Details of the financing structures used for each project are described in Section 4 of the full report. In most cases, these are first-of-their-kind structures that could serve as useful examples for other projects - both community and commercial wind alike.

Much as the partnership flip structure was first devised in response to the specific nature of federal policy support for wind power projects - specifically, the inability of most individuals to make efficient use of the production tax credit ("PTC") and accelerated depreciation - so too has this new wave of financial innovation in the community wind sector been driven by policy changes, most of them recent. For example, as described in Section 3 of the full report, the American Recovery and Reinvestment Act of 2009 enables, for a limited time, wind power (and other types of) projects to elect either the 30\% investment tax credit ("ITC") or a $30 \%$ cash grant (the "Section 1603 grant") in lieu of the PTC. This flexibility, in turn, enables wind power projects to pursue lease financing for the first time - neither the ITC nor the cash grant is subject to the PTC's requirement that the project owner also operate the project in order to be eligible for the incentive. The ITC and Section 1603 grant also reduce performance risk relative to the PTC, and (unlike the PTC) neither the ITC nor the grant is penalized for the use of subsidized energy financing. Finally, by providing a cash rather than tax incentive, the cash grant alone reduces (but does not eliminate) the need for tax appetite among project owners. All of these policydriven changes can be particularly useful to community wind projects. 
Other policy-related enablers of some of the financial innovation profiled in this report include New Markets Tax Credits - which are not new but have only recently been tapped to help finance solar projects and, for the first time, in 2010 have been part of a community wind project financing - and Section 6108 of the 2008 Farm Bill, which expands the USDA's authority to loan to renewable generation projects, even if those projects are not serving traditional rural markets.

The collective experiences of the five community wind projects profiled in Section 4 of the full report can be distilled into the following common observations or lessons learned (described further in Section 5 of the full report) regarding the development and financing process:

- The Recovery Act, and in particular the Section 1603 cash grant, has been critically important to most of these projects. Although the deadline to qualify for the grant has been extended through 2011, wind projects must still be online by the end of 2012 to receive the grant or ITC in lieu of the PTC (which is also currently slated to expire at the end of 2012). Efforts to extend one or more of these incentives will no doubt be underway throughout 2011 and 2012, but at present the window of opportunity to take advantage of the grant in particular is relatively short.

- Don't overlook the need for seed capital. Many analysts and financiers tend to focus on construction and permanent financing, but most of the projects reviewed in this report had spent upwards of half a million dollars in seed capital before even getting to the construction financing stage. Raising this amount of seed capital - much of which is spent on relatively fixed development costs - can be a significant hurdle for community wind projects, and in particular smaller community wind projects.

- Piggybacking on nearby projects can help ease the burden. One project reviewed in this report was under construction within a year of being conceived, thanks in large part to the benefits of piggybacking on (i.e., leveraging) another project's development work.

- Partnering with experienced professionals can create opportunities. Although the projects profiled in this report are modest in size, they are nevertheless complex undertakings involving novel financing structures, which in many cases represent industry firsts. Most of these projects have benefited greatly from the assistance of experienced financial consultants or advisors.

- Consider the RUS as a source of debt. The USDA's Rural Utility Service has traditionally financed infrastructure associated with rural electric cooperatives, but does have the authority to lend to standalone wind projects on a non-recourse basis, and has done so at least twice in the past two years. Moreover, a provision in the 2008 Farm Bill makes it easier for the RUS to loan to wind projects, even if they're not serving traditional rural markets. RUS debt is typically guaranteed by the USDA, and therefore has a very attractive interest rate.

- Don’t overlook New Markets Tax Credits (“NMTCs”). Given their typically small size, community wind projects should generally strive for greater simplicity rather than increased complexity in financing structures. The realities of the market, however, often 
require that complex financing structures be employed in order to maximize available incentives. For this reason, NMTCs are worth keeping in mind should an appropriate opportunity present itself. Although NMTCs can be complex to structure, they do provide quite a bit of value (on a present value basis, effectively the equivalent of a second ITC), which in some cases could justify the high transaction costs of pulling together an NMTC deal.

- Be prepared for a long haul. Three of the five projects profiled in this report have endured development cycles of five years or longer, which requires patience, tenacity, and adequate development capital.

- The shift from construction to operations can bring new challenges. Although this report focuses primarily on project financing, the challenges do not necessarily end once a project has been financed and built. Several of the projects reviewed in this report have recently shifted from the construction phase to the operational phase, and are now facing operational challenges ranging from integration issues to complying with noise regulations. 


\section{Introduction}

In the United States, the "community wind” sector - loosely defined here as consisting of relatively small utility-scale wind power projects that sell power on the wholesale market and that are developed and owned primarily by local investors ${ }^{1}$ - has historically served as a "test bed" or "proving grounds" for up-and-coming wind turbine manufacturers that are trying to break into the U.S. wind power market. For example, community wind projects - and primarily those located in the state of Minnesota - have deployed the first U.S. installations of wind turbines from Suzlon (in 2003), DeWind (2008), Americas Wind Energy (2008) and later Emergya Wind Technologies (2010), Goldwind (2009), AAER/Pioneer (2009), Nordic Windpower (2010), Unison (2010), and Alstom (2011). Thus far, one of these turbine manufacturers - Suzlon - has subsequently achieved some success in the broader U.S. wind market as well.

Just as it has provided a proving grounds for new turbines, so too has the community wind sector served as a laboratory for experimentation with innovative new financing structures. For example, a variation of one of the most common financing arrangements in the U.S. wind market today - the special allocation partnership flip structure (see Figure 1 in Section 2.1) - was first developed by community wind projects in Minnesota more than a decade ago (and is therefore sometimes referred to as the "Minnesota flip" model) before being adopted by the broader wind market. More recently, a handful of community wind projects built over the past year have been financed via new and creative structures that push the envelope of wind project finance in the U.S. - in many cases, moving beyond the now-standard partnership flip structures involving strategic tax equity investors. These include:

- a 4.5 MW project in Maine that combines low-cost government debt with local tax equity,

- a 25.3 MW project in Minnesota using a sale/leaseback structure,

- a 10.5 MW project in South Dakota financed by an intrastate offering of both debt and equity,

- a 6 MW project in Washington state that taps into New Markets Tax Credits using an "inverted" or "pass-through" lease structure, and

- a 9 MW project in Oregon that combines a variety of state and federal incentives and loans with unconventional equity from high-net-worth individuals.

In most cases, these are first-of-their-kind structures that could serve as useful examples for other projects - both community and commercial wind alike.

This report describes each of these innovative new financing structures in some detail, using a case-study approach. The purpose is twofold: (1) to disseminate useful information on these

\footnotetext{
${ }^{1}$ Other, more-complex - though not necessarily more-rigid - definitions of community wind exist. See, for example, the first page of AWEA (2010) for the definition of community wind adopted by the American Wind Energy Association ("AWEA"). Without getting bogged down in specific aspects of various definitions, it is nevertheless important to emphasize here that this report will not cover individual wind turbines or projects that are interconnected on the ratepayer side of the electric meter to displace power purchased from the local utility - even though such projects are most often considered to be community wind projects. Instead, this report focuses exclusively on community wind projects that deliver electricity to the broader distribution or transmission grid and sell it on the wholesale market.
} 
new financial structures, most of which are widely replicable; and (2) to highlight the recent policy changes - many of them temporary unless extended - that have facilitated this innovation. Although the community wind market is currently only a small sub-sector of the U.S. wind market - as defined here, less than 2\% of the overall market at the end of 2009 (Wiser and Bolinger 2010) - its small size belies its relevance to the broader market. ${ }^{2}$ As such, the information provided in this report has relevance beyond its direct application to the community wind sector.

The next two sections of this report briefly summarize how most community wind projects in the U.S. have been financed historically (i.e., prior to this latest wave of innovation) and describe the recent federal policy changes that have enabled a new wave of financial innovation to occur, respectively. Section 4 contains brief case studies of how each of the five projects mentioned above were financed, noting the financial significance of each. Finally, Section 5 concludes by distilling a number of general observations or pertinent lessons learned from the experiences of these five projects.

\footnotetext{
${ }^{2}$ For example, as noted above, the community wind sector provides a valuable service as a "proving grounds" for up-and-coming wind turbine manufacturers, as well as a test bed for financial innovation. In addition, by retaining more of wind power's economic benefits within the local community, community wind can enhance public acceptance of wind power and broaden the investor base. Community wind has also tended to be countercyclical to the broader wind market (e.g., due to turbine availability issues and less dependence on Wall Street), thereby providing ongoing demand for industry services during otherwise slack periods. Finally, the community wind sector is, in some ways, a more-transparent microcosm of the larger U.S. wind market, thereby bringing policy needs into sharper relief (e.g., even though many independent commercial wind developers face the same barriers to using federal tax incentives as do community wind investors, those barriers are sometimes harder to identify among commercial wind projects, because they are obscured by layers of corporate structuring).
} 


\section{How Community Wind Projects Have Traditionally Been Financed}

This section briefly summarizes how most community wind projects (again, as defined for the purposes of this report) in the United States have been financed in the past: using partnership flip structures and private placements. The purpose is not to rehash the work that has come before; readers in need of more background or detail should consult the earlier literature, which includes Bolinger (2010), Bolinger and Karcher (2009), Bolinger et al. (2009), and Bolinger and Wiser (2006). Instead, the purpose of this section is simply to establish a benchmark against which to compare the five financing structures profiled later in Section 4.

\subsection{Partnership Flip Structures}

Within the narrow definition of community wind used in this report - i.e., relatively small utilityscale wind power projects that sell power on the wholesale market and that are developed and owned primarily by local investors - the majority of so-defined projects in the United States have been financed using one form or another of a "partnership flip structure." In its most basic form (see Figure 1, adapted from Bolinger et al. 2009), a partnership flip structure involves the local project sponsor partnering with a tax equity investor to capitalize a special purpose entity that builds and operates the project. The tax equity investor provides most of the equity for the project (99\% in Figure 1), and in return is initially allocated most (also 99\%) of the cash and tax benefits generated by the project. Cash benefits include revenue from the sale of power and renewable energy certificates ("RECs") and possible receipt of the Section 1603 cash grant (if chosen in lieu of the PTC or ITC), while tax benefits include tax losses from accelerated depreciation deductions and tax credits from the production tax credit ("PTC") or investment tax credit ("ITC"). Once the tax equity investor has achieved an agreed-upon target internal rate of return ("IRR") - typically projected to occur shortly after the end of the project's $10^{\text {th }}$ year under the PTC, but earlier under the ITC or Section 1603 grant - then both the cash and tax allocations "flip" in favor of the local sponsor (from 1\% to 95\% in Figure 1, where forward slashes are used to distinguish between pre- and post-flip allocations of the distributable cash and tax benefits denoted by the gray boxes). In most cases, after the flip has occurred, the sponsor has an opportunity to buy out the tax equity investor's now-greatly-diminished interest (e.g., 5\%) in the project. $^{3}$

\footnotetext{
${ }^{3}$ The pre- and post-flip allocations shown in Figure 1 are essentially as aggressive as they could be while still falling within the "safe harbor" guidelines provided by the IRS in Revenue Procedure 2007-65. In practice, however, the post-flip allocations to the tax equity investor in particular may need to be higher than the $5 \%$ shown in Figure 1, in order to comply with partnership accounting rules involving capital account balances (Martin 2008).
} 


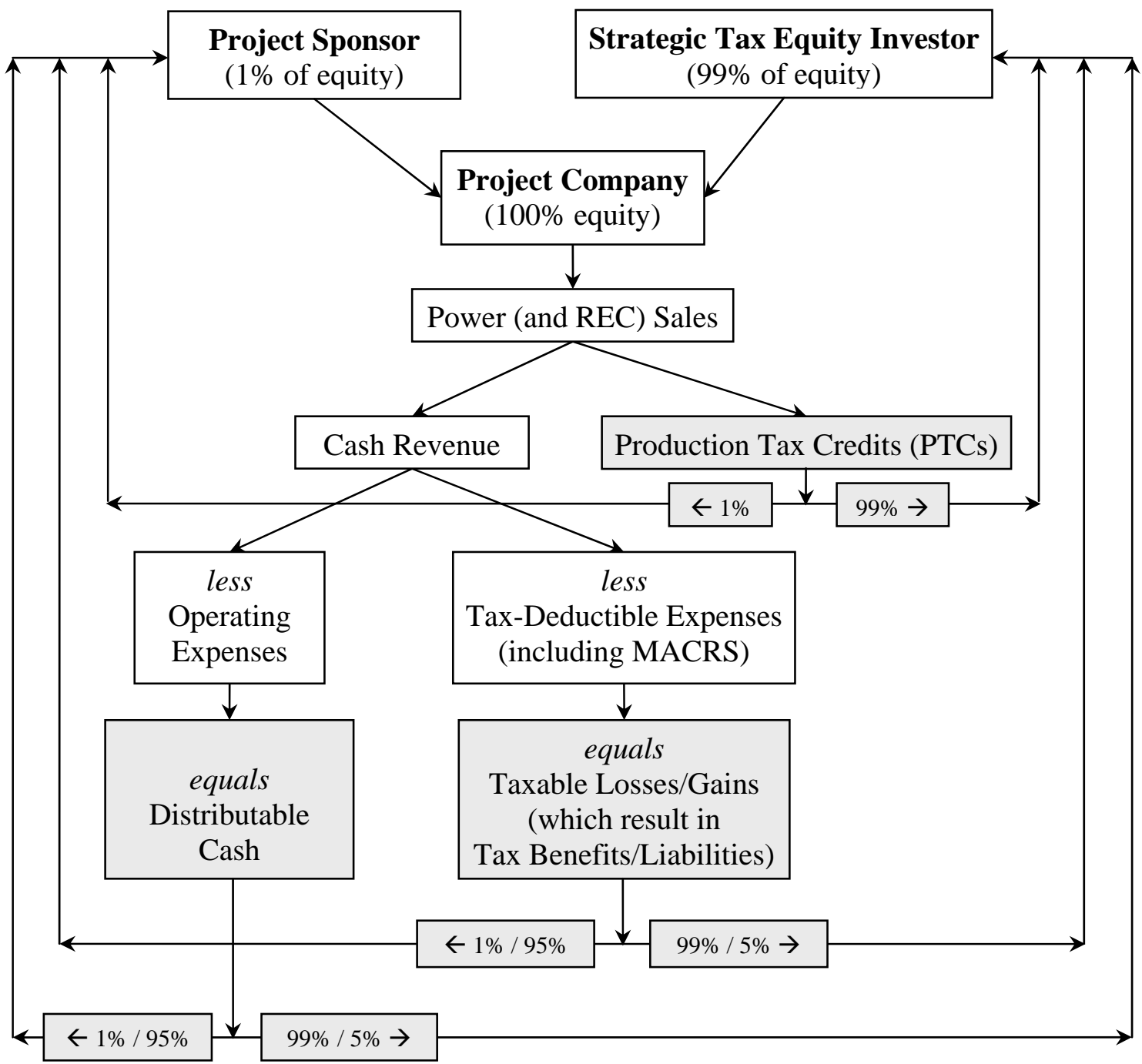

Figure 1. Schematic of Strategic Investor Flip Structure Using the PTC (forward slashes distinguish between pre- and post-flip allocations of distributable benefits)

Partnering with a tax equity investor in this manner has typically been necessary because the local project sponsor often does not have sufficient income tax liability to efficiently absorb either the tax losses generated by accelerated depreciation or the tax credits generated by the PTC (or ITC). A tax equity investor can "monetize" these tax benefits on behalf of the project, while also injecting much-needed capital. In most cases, tax equity investors who invest in community wind projects are "strategic" investors - i.e., investors with tax credit appetite that have a strategic interest in the wind sector and who take an active role in the project. Examples from the past include Edison Mission Energy and John Deere Wind. ${ }^{4}$

\footnotetext{
${ }^{4}$ Strategic tax equity investors such as Edison Mission and John Deere are typically more appropriate for community wind projects than are the institutional tax equity investors - i.e., the large banks and insurance companies such as JPMorgan and MetLife - that have invested in the commercial wind sector. This is because, unlike most institutional tax equity investors, strategic investors often have access to turbines, are willing to invest in a project prior to construction, may not require as much of an equity investment from the project sponsor, can sometimes provide O\&M services, and may be willing to stay invested in a project post-flip if necessary - all of which can provide value to community wind projects (Bolinger and Karcher 2009).
} 


\subsection{Private Placements}

A second way in which community wind projects have historically raised construction and permanent financing is through a "private placement" of equity shares in the project. In a private placement, the project sponsor sells equity shares in the project directly to local investors, most of whom must meet the Securities and Exchange Commission's ("SEC") definition of an "accredited" or sophisticated investor. The sponsor is not allowed to publicly advertise the offering, and must follow a number of other anti-fraud regulations laid out by the SEC (see Section 4.2.1 of Bolinger et al. 2004). Cash and tax benefits are distributed to investors in proportion to their ownership stake in the project, and most investors will take their individual tax situation into account when deciding how much to invest (i.e., presumably few will invest an amount that will generate more tax losses and credits than they can efficiently absorb). Typically, roughly half of the project's total construction cost is raised through the private placement of equity, and the remainder is financed through a bank loan.

Although there are examples of private placements used to raise construction and permanent financing for community wind projects - e.g., the Minwind I-IX projects in southwestern Minnesota - in general private placements have been much less common than partnership flip structures. ${ }^{5}$ The reason is that it can be difficult to find individual investors who have sufficient passive income from other sources (i.e., sources other than the wind project) to enable efficient use of the passive depreciation losses and tax credits generated by investment in a wind project. ${ }^{6}$ This problem is exacerbated by the inability to publicly advertise the offering without running afoul of SEC regulations. Thus, even though spreading the equity investment across multiple individual investors reduces the absolute amount of passive tax appetite required by any individual investor, finding a sufficient number of such investors to adequately capitalize a project can be challenging. ${ }^{7}$ For this reason, most community wind projects have instead partnered with (via a partnership flip structure as described above) a strategic tax equity investor that can - at a cost - monetize the tax benefits on behalf of the project. ${ }^{8}$

\footnotetext{
${ }^{5}$ This statement applies only to the relatively rare use of private placements to raise construction and permanent financing. Private placements are, however, more often employed as a way to raise seed or development capital from local investors, who are later repaid by construction and/or permanent financing obtained via other means. ${ }^{6}$ Most individual investors in a wind project will likely be considered by the IRS to be passive investors, which means that depreciation losses from the project can only offset passive income, and tax credits from the project can only offset tax liability generated by passive income. Since the project itself is not likely to generate income for a number of years (due to accelerated tax depreciation, which generates large losses in the early years), additional passive income from other sources outside of the project are needed to efficiently absorb wind project-related depreciation losses and tax credits. In general terms, passive income is defined by the IRS to be income that is derived from either (i) a trade or business in which the taxpayer does not materially participate (with material participation determined by at least one of seven tests) or (ii) rental income, unless the taxpayer is a real estate professional (for more detail, see IRS Publication 925 at http://www.irs.gov/pub/irs-pdf/p925.pdf). Notably, passive income does not include wage or investment portfolio (e.g., interest or dividend) income - i.e., the most common types of income for most individuals.

${ }^{7}$ The nine Minwind projects succeeded by tapping into the same group of farmers who had collectively invested in a local ethanol plant. The ethanol investment provided an external source of passive income, against which passive depreciation losses and tax credits from the wind projects could be applied.

${ }^{8}$ Most tax equity investors are C-corporations, which are not subject to the passive activity limitations described earlier in footnote 6. According to IRS Publication 925, passive activity limitations apply to individuals, estates, trusts (other than grantor trusts), personal service corporations, and closely held corporations. They also apply to the owners of grantor trusts, partnerships, and S-corporations.
} 


\section{Recent Policy Changes Have Facilitated Financial Innovation}

The partnership flip structures and private placements described in the previous section were developed by community wind projects in Minnesota roughly a decade ago, during what could be described as the first wave of financial innovation within the community wind sector. More recently, this past year has witnessed what might be considered a second wave of financial innovation within the community wind sector, featuring a number of projects that have moved beyond the now-standard partnership flip structures. Several of these projects will be featured in Section 4 of this report.

In many ways, this new wave of financial innovation occurring in the community wind sector has been facilitated by policy changes, most of them recent. Most notably, the American Recovery and Reinvestment Act of 2009 ("the Recovery Act") enables, for a limited time, wind power (and other types of) projects to elect either the 30\% ITC or a 30\% cash grant (the "Section 1603 grant”) in lieu of the PTC. This flexibility, in turn, enables wind power projects to pursue lease financing for the first time - neither the ITC nor the grant is subject to the PTC's requirement (in Section 45(a)(2)(A) of the Internal Revenue Code) that the project owner also operate the project in order to be eligible for the incentive. Because they are based on a project's cost rather than energy generation, the ITC and Section 1603 grant also reduce performance risk relative to the PTC - this, too, is an important enabler of lease financing, as discussed in the case studies that follow. Unlike the PTC, neither the ITC nor the grant is penalized for the use of subsidized energy financing. Finally, by providing a cash rather than tax incentive, the Section 1603 grant alone reduces (but does not eliminate) the need for tax appetite among project owners. ${ }^{9}$ All of these policy changes can be particularly useful to community wind projects (Bolinger 2010), and have helped to support the financial structures discussed in Section 4.

New Markets Tax Credits ("NMTCs") are not new - they were established in 2000, with the first allocation in 2001 - but have only recently been tapped to help finance solar projects (see, for example, NREL 2010), and now for the first time have been used to help finance a community wind project built in 2010. NMTCs provide an investment tax credit of 39\% over seven years $5 \%$ in each of the first three years, and 6\% in each of the final four - for a Qualified Equity Investment ("QEI") in a Community Development Entity (“CDE”). The CDE, in turn, channels "substantially all” (i.e., less fees) of the QEI into a loan or equity investment for a qualifying low-income business - e.g., a company established to own and operate a community wind project within a NMTC-qualifying census tract. Because NMTC's are once-removed from a project, in that they flow from the QEI in the CDE rather than from a direct investment in a project, they are unlikely to trigger anti-double-dipping penalties or "haircuts" when taken in conjunction with the PTC, ITC, or cash grant. As such, a wind project financed using both NMTC's and the ITC, for example, could see roughly $60 \%$ (on a present value basis) of installed project costs returned through just these two tax credits.

Finally, Section 6108 of the 2008 Farm Bill expands the USDA's authority to loan to renewable generation projects, even if those projects are not serving traditional rural markets. Specifically,

\footnotetext{
${ }^{9}$ Tax appetite is still required to make efficient use of accelerated depreciation deductions.
} 
Section 6108 (titled "Electric Loans for Renewable Energy") reads: "In addition to any other funds or authorities otherwise made available under this Act, the Secretary may make electric loans under this title for electric generation from renewable energy resources for resale to rural and nonrural residents." (italics added) This clause potentially makes low-cost debt financing from the USDA's Rural Utility Service ("RUS") available to a wide array of wind projects, even those not associated with rural electric cooperatives.

Much as the partnership flip structure was first devised in response to the specific nature of federal policy support for wind power projects - specifically, the inability of most individuals to make efficient use of the PTC and accelerated depreciation - so too has the most recent innovation in the financing of community wind projects been driven by the policy changes described above (and most notably, the Recovery Act). 


\section{Five Recent Projects Exemplify the Breadth of Innovation}

This section describes, in case study format, how five community wind projects that are either recently operational or currently under construction have capitalized on the policy changes described in Section 3 to pursue financial structures that mark significant departures from the partnership flip structures and private placements described in Section 2. These five wind projects in five different states across the U.S. represent a number of "firsts" - not just for the community wind sector, but for the U.S. wind market as a whole. These include the first lowcost RUS loan to a wind project (used in conjunction with tax equity), the first sale/leaseback of a wind project, the first intrastate offering combining debt and equity (and likely the first intrastate offering to go to construction), and the first wind project to use not only New Markets Tax Credits, but also an "inverted" or "pass-through" lease structure. Each of these projects is described below, starting off the coast of Maine and proceeding westward.

\subsection{Fox Islands Wind, LLC}

\section{Background}

Twelve miles off the coast of Maine, a 4.5 MW wind project (consisting of three GE 1.5 MW turbines) has been generating power on the island of Vinalhaven since November 2009. All of the electricity from the project is sold, at cost, to the Fox Islands Electric Cooperative ("the Cooperative"), which is the local electric provider for both Vinalhaven and its neighbor island, North Haven. ${ }^{10}$ When winds are light and the Cooperative's load exceeds the amount of available wind generation, the shortfall is purchased from the mainland and transmitted via underwater cable. The reverse happens when the amount of wind generation exceeds the Cooperative's load - excess power is sold via the cable to the mainland. Because electricity transmitted from the mainland via the cable is quite expensive, the wind project should help the Cooperative to significantly reduce its overall cost of power.

\section{Financing Details}

The installed cost of the Fox Islands project is estimated to be $\$ 14.5$ million, or $\$ 3,222 / \mathrm{kW}$. This relatively high per-unit cost can be attributed primarily to the logistical challenges of transporting and then barging the three turbines (in addition to construction equipment, including cranes) to the island site, as well as the lack of economies of scale in such a small project. In addition, the novelty of the financing structure - described below - was time-consuming.

Although the history of the project extends back to 2001 and involves a variety of entities and individuals, ${ }^{11}$ this discussion focuses solely on the project financing and the main players

\footnotetext{
${ }^{10}$ Separately, the first 5 years' worth of RECs from the project have been sold to the Cape Light Compact in Massachusetts at a fixed price of \$30.60/MWh.

${ }^{11}$ For example, as far back as 2002, the Fox Islands Electric Cooperative had secured a grant for a three-year wind resource study to be conducted by the University of Massachusetts Renewable Energy Research Laboratory. Later, the Island Institute - a non-profit community development organization that focuses on the island communities in the Gulf of Maine - provided the Cooperative with early technical and financial assistance for pre-feasibility work,
} 
involved. The first of these players is the Fox Islands Electric Cooperative, which not only serves as the power offtaker (as described above), but is also the project sponsor. Because it is a non-taxable entity that is unable to make use of federal tax incentives for wind power, the Cooperative formed a for-profit subsidiary - Fox Islands Wind, LLC - to own the wind project. Initially, the Cooperative was the sole member of Fox Islands Wind, LLC.

Shortly after resident islanders voted in July 2008 to authorize the Cooperative to proceed with the project, Fox Islands Wind, LLC raised \$350,000 in seed capital by issuing contingent promissory notes to (i.e., by borrowing money from) private individuals and foundations. This seed capital was used to finance the remaining engineering, legal, and environmental studies required to secure the necessary permits.

The project also secured a $\$ 9$ million construction loan from the Cooperative Finance Corporation - a private non-profit cooperative that was formed to supplement the loan programs for electric cooperatives offered by the USDA's Rural Utilities Service ("the RUS"). Because the Cooperative Finance Corporation will only loan to cooperatives, the Fox Islands Electric Cooperative was nominally the borrower, and passed the proceeds through to Fox Islands Wind, LLC (Baker 2010).

Rounding out the construction financing was a $\$ 5$ million tax equity investment from a local business (Diversified Communications, a media company headquartered in Portland, Maine) in exchange for a 99\% interest in Fox Islands Wind, LLC.

Permanent financing includes not only the $\$ 5$ million equity contribution from Diversified Communications, but also a $\$ 9.5$ million 20-year term loan from the RUS. This term loan will repay both the $\$ 9$ million construction loan and the $\$ 350,000$ (plus interest) in promissory notes. The vehicle for the term loan is a Federal Finance Bank (FFB) loan that is guaranteed by the USDA - i.e., an "FFB Guaranteed loan." Because of the government guarantee, the interest rate is quite attractive - priced at comparable-term Treasury yields plus $0.125 \%$. For the Fox Islands Wind project (which had not yet drawn down the loan or locked in the interest rate at the time of writing), the interest rate is likely below $3.5 \%$.

Once the project achieved commercial operations in November 2009, Diversified Communications benefitted from the $30 \%$ ITC as well as accelerated tax depreciation (or rather, $99 \%$ of both of these tax benefits). ${ }^{12}$ Because Diversified Communications is an $\mathrm{S}$ corporation (as opposed to a $\mathrm{C}$ corporation), its allowable depreciation deductions are limited to its $\$ 5$ million equity stake - the result of S-corp basis limitations (Baker 2010). With 50\% bonus depreciation in place for 2009, this $\$ 5$ million limit was reached in the 2009 tax year. Thus, going forward, Diversified Communications will not take any further federal tax benefits out of the project; it will, however, maintain its ownership interest for at least five years (receiving a

public education, and outreach. For more background information on this project, see the comprehensive summary available on the Fox Islands Wind Project website (http://www.foxislandswind.com/background.html).

${ }^{12}$ Diversified Communications elected the 30\% ITC rather than the 30\% Section 1603 cash grant because of initial uncertainty over eligibility for the Section 1603 grant, given that one of the two members of Fox Islands Wind, LLC - the Cooperative - is a tax-exempt entity. By the time clarifying regulations were issued by the Treasury (e.g., regarding "blocker corporations"), the project had already proceeded far enough along the ITC path that it did not make sense to change course (Baker 2010). 
nominal cash dividend each year) in order to avoid recapture of the ITC. At the end of five years, Fox Islands Electric Cooperative hopes to buy out Diversified Communications' interest in Fox Islands Wind, LLC. ${ }^{13}$

\section{Significance}

In addition to its significance as an engaging story - i.e., a photogenic island wind power project that overcame significant logistical hurdles to reduce local electricity costs - the Fox Islands Wind project is also significant in the way it was financed. Most notably, the 20-year RUS term loan is the first loan that the RUS has offered to a wind project on a project finance basis. It is also, therefore, the first time that a low-interest RUS loan has been combined with federal tax incentives and investors interested in those incentives. Combining these two historically separate instruments of finance - i.e., low-cost government debt and tax equity leveraging federal tax incentives - helped make even this relatively expensive project (at least on a \$/MW installed cost basis) financeable.

Historically, the RUS is accustomed to lending to established rural electric cooperatives, rather than stand-alone projects. But in order for this project to also benefit from federal tax incentives, it had to be owned by the standalone Fox Islands Wind LLC (which in turn is principally owned by the local tax equity investor), rather than by the Fox Island Electric Cooperative. It took some time for the RUS to gain comfort with this type of borrower and loan - a process that was no doubt helped by fairly stringent reserve requirements (Baker 2010).

Another important aspect of the RUS loan is the "FFB Guaranteed" vehicle through which it is delivered - i.e., the RUS loans the funds (through the FFB) and the USDA guarantees the loan. This is important because the IRS has previously held that government loan guarantees are not considered to be government-subsidized financing. Although the Recovery Act eliminated the "subsidized energy financing” haircut for the 30\% ITC and cash grant (Bolinger 2010), that haircut is still intact for the PTC - i.e., the value of the PTC will be reduced proportionally by the amount of government-subsidized financing used by a project. The distinction between subsidized financing and loan guarantees is moot for the Fox Islands Wind project (as Diversified Communications elected the 30\% ITC), but could be important for other wind projects, particularly going forward if/when access to the ITC and cash grant expires, potentially leaving the PTC as the only remaining federal incentive. The Fox Islands Wind experience suggests that in such a circumstance, RUS loans could be combined with the PTC without penalty, thereby providing additional value to wind projects.

\footnotetext{
${ }^{13}$ The fair market value of Diversified Communications' 99\% interest in the project should be relatively low at that time, because (A) virtually all of the tax benefits accruing to the project will already have been realized, and (B) the project generates very little net income, since it essentially sells its power to the Cooperative at cost.
} 


\subsection{Ridgewind Power Partners, LLC}

\section{Background}

The 25.3 MW Ridgewind project is located along the Buffalo Ridge in Pipestone, Minnesota. Developed by Project Resources Corporation ("PRC”) out of Minneapolis through the specialpurpose entity Ridgewind Power Partners, LLC, the project consists of eleven Siemens 2.3 MW turbines. Power and RECs from the project will be sold to Xcel Energy under a 20-year contract. The project achieved commercial operations in December 2010.

\section{Financing Details}

Union Bank (based in California) provided \$51 million in construction financing, which will be repaid soon after the commencement of commercial operations by the sale of the project's hard assets to a Union Bank affiliate. Ridgewind Power Partners, LLC will then lease the project assets back for a 20-year term, during which it will manage and operate the project. Once this sale/leaseback financing has closed and the project is operating as planned, PRC will expand community ownership by implementing its Minnesota Windshare program, which will open up a portion of Ridgewind Power Partners, LLC to local investment. ${ }^{14}$

The Union Bank affiliate (the lessor) will benefit from the Section 1603 cash grant (equal to roughly $30 \%$ of the project's cost), $100 \%$ of accelerated depreciation deductions, and regular lease payments. Ridgewind Power Partners, LLC (the lessee) will benefit from power sales revenue in excess of operating costs and lease payments. At the end of the 20-year lease term (and perhaps even earlier), Ridgewind Power Partners, LLC will have an opportunity to buy back the project's hard assets from the Union Bank affiliate.

\section{Significance}

This is the first sale/leaseback financing of a wind project. ${ }^{15}$ Prior to the Recovery Act, lease financing was essentially unavailable to wind projects taking the PTC by the requirement in Section 45(a)(2)(A) of the tax code that the project owner also operate the project. This requirement is contrary to the basic definition of a lease, which involves two separate entities the lessor who owns the project and the lessee who operates it. No such requirement exists, however, for the 30\% ITC or the Section 1603 cash grant, both of which became available to wind projects in the wake of the Recovery Act.

Although lease financing has been popular in the commercial solar sector for a number of years, some traditional tax equity investors have questioned the potential role of lease financing in the wind sector due to wind power's greater inter-year variability relative to solar (a bad wind year

\footnotetext{
${ }^{14}$ For general information on PRC’s Minnesota Windshare program, see http://www.projectresources.net/.

${ }^{15}$ Shortly after Ridgewind's announcement, Terra-Gen Power announced that its Alta II-V wind projects totaling 570 MW in Tehachapi, California, would be financed using a leveraged lease structure. In early 2011, Terra-Gen Power announced that its Alta I project had entered into a sale/leaseback structure with GE Energy Financial Services and a Union Bank subsidiary acting as co-lessors. Several other wind projects in development are reportedly also working on lease financing structures (White 2010).
} 
might result in production that is $10 \%-15 \%$ lower than expected). Given that a lease requires the lessee to make regular fixed payments over time - independent of how well the project performs - wind's greater variability makes leasing a risky proposition.

Both the lessee and the lessor of the Ridgewind project have noted, however, that the risk is little different from that which is regularly assumed by lenders to wind projects - i.e., lenders also require generally fixed payments that are independent of how well a project performs. Both a lender and a lessor will evaluate performance risk by assessing the likely amount of cash revenue that will be generated under poor wind (e.g., P90-P99) conditions, and determining whether that revenue is sufficient to meet debt service or lease payments. A lender, however, can always manage the degree of performance risk it is willing to accept by sizing the debt appropriately (e.g., through debt service coverage requirements), whereas a lessor does not have this luxury, as it must finance the full cost of the project.

This is where two fundamental differences between the 10-year PTC and the 30\% ITC (or cash grant) come into play: (1) the ITC and cash grant are realized during the project's first year, rather than over 10 years as is the case for the PTC, and (2) there is no performance risk associated with the $30 \%$ ITC or cash grant. These differences mean that, under the grant or ITC, only $70 \%$ (rather than 100\%) of project costs must be financed (long-term) by the lessor and are at risk of poor project performance. Furthermore, accelerated depreciation deductions - and even 50\% (or 100\% in 2011) first-year "bonus" depreciation for projects brought online before the end of 2012 - are also captured regardless of how well the project performs. In combination, enough of the lessor's return is provided through up-front cash and/or tax benefits (and, moreover, cash and/or tax benefits that are insulated from performance risk) that lease payment amounts can be set low enough to have a sufficiently high probability of being paid, even in poor wind years.

From a community wind perspective, lease financing offers three attractions. The first is simplicity: dealing with just a single entity for both construction and permanent financing simplified the Ridgewind financing process and eliminated the possibility of thorny inter-creditor issues that can often arise between tax equity investors and lenders. Second, the lessor takes $100 \%$ of the tax benefits, which means that project sponsors or other local investors need not have any tax appetite at all (in a partnership flip structure, the sponsor must take at least $1 \%$ of the tax benefits, whether or not it can use them). Finally, lease financing could potentially broaden the base of tax investors interested in wind projects. Although many of the large institutional tax equity investors typically won't bother with smaller community wind projects (the fact that Ridgewind was able to work with a tax equity investor as prominent as Union Bank is notable in this regard), many smaller banks have affiliated leasing companies that might be more amenable to such projects.

Lease financing is not, however, a panacea for community wind. Because performance risk can, as described above, be more of an issue with lease financing, choice of turbine becomes that much more important. Ridgewind's use of a "tier-one” turbine supplier - Siemens - no doubt enhanced Union Bank's comfort that the project will perform as expected, thereby increasing the likelihood that lease payments will be made on time. Whether smaller community wind projects 
can continue to attract the attention of tier-one turbine suppliers in future years remains to be seen, and will likely depend on how long the current buyer's market persists.

In addition, Ridgewind attributes much of its ability to initially "get its foot in the door" at Union Bank to the fact that it was working with an experienced financial consultant (Miracol Energy) with former ties to large institutional tax equity investors (White 2010). Without the assistance of this intermediary, Union Bank may not have been willing to work with Ridgewind - i.e., the transaction costs of working with smaller projects can be too great given the relatively small size of the investment.

Finally, the Ridgewind project is notable in that it plans to expand community ownership by implementing its Minnesota Windshare program after the project is up and running. Waiting until the project is operational simplifies the original financial close (Union Bank dealt with just a single counterparty), simplifies the offering to local investors (the prospectus can be considerably shorter given no construction risk), and should reduce the risk to local investors (while still offering competitive returns). This approach stands in contrast to other community wind models that raise high-risk, early-stage development capital from local investors.

\subsection{South Dakota Wind Partners, LLC}

\section{Background}

South Dakota Wind Partners, LLC (“SDWP”) is a 10.5 MW project that is located adjacent to the larger 151.5 MW PrairieWinds SD1 project owned by Basin Electric Power Cooperative (“Basin”). Specifically, SDWP is "piggybacking” on the development, construction, and operation of PrairieWinds SD1, which was permitted for 110 GE 1.5 MW turbines, but will only use 101, enabling SDWP to take over the permits for seven of the remaining nine open locations. Although SDWP is owned and financed separately from PrairieWinds SD1, Basin is constructing and will operate both projects, will buy the electricity generated by SDWP's turbines, and may eventually buy the SDWP project outright. The project was under construction at the time of writing, with expectations to become operational during the first half of 2011.

The SDWP project originated with East River Electric Power Cooperative ("East River”), a generation and transmission cooperative that delivers wholesale power to 25 member electric distribution systems in eastern South Dakota and western Minnesota. East River itself obtains nearly $80 \%$ of its power supply from Basin - the developer, owner, and operator of PrairieWinds SD1 - and so has a close working relationship with the larger cooperative. In October 2009, East River approached Val-Add Service Corporation of Sioux Falls with the basic idea for the SDWP project, and Val-Add spent the next month conducting fatal flaw analysis and fleshing out the details. East River presented the refined vision for the SDWP project to Basin in December 2009 and then again in January 2010, at which point Basin agreed to the idea. Having secured Basin's approval, East River brought in three agricultural organizations - the South Dakota Corn Utilization Council, the South Dakota Farmers Union, and the South Dakota Farm Bureau - to serve as co-founders and help encourage a broad base of support for and investment in the project. Each of these three organizations (as well as East River itself) was motivated by 
the prospect of creating economic opportunity for its members - both in terms of being able to invest in the project, as well as potentially benefiting from the local jobs that it would create.

\section{Financing Details}

SDWP was financed primarily through what's known as an "intrastate offering," which is one of two ways (the other being a "private placement," as described earlier in Section 2.2) in which "securities" can be offered to members of the public without having to formally register those securities with the SEC. ${ }^{16}$ As the name implies, an intrastate offering requires that the business offering the securities is incorporated in the same state where the securities are being offered, will carry out a significant portion of its business there, and will only offer or sell securities to residents of that state (who, in turn, cannot re-sell their securities for a full year, at which point they are free to sell them even to non-residents). Intrastate offerings can be, and are, widely advertised and marketed to residents. In contrast, a "private placement” involves offering securities in a non-public manner to primarily "accredited" or sophisticated investors who meet certain requirements (Section 4.2.1 of Bolinger et al. (2004) provides more details on the requirements for a private placement).

In general, a community wind project offering only equity shares might find a private placement to be more manageable than an intrastate offering, because only certain types of equity investors - e.g., those with other sources of passive income - will be able to efficiently absorb the tax credits and depreciation losses from a passive investment in a wind project. As such, it makes sense to target those types of investors directly, which can be more efficiently accomplished through a private placement. In this case, however, SDWP offered three different investment options (described below), each comprised of a different blend of debt and equity, thereby enabling prospective investors to select the option that most closely fit their tax appetite. This self-selection process reduced the need to target specific investor types and allowed SDWP to open up the offering to all South Dakota residents.

Initially, the four founding members each provided a \$20,000 grant to launch SDWP. Other SDWP board members (i.e., other than the founding members) contributed an additional $\$ 300,000$, and SDWP spent the resulting $\$ 380,000$ on consultants, attorneys, and accountants needed to set up and market the offering. Prospective investors were asked to attend one of twenty-seven publicly advertised informational meetings held throughout the state in August and September 2010, and by the end of September - i.e., in just eight weeks - SDWP had reached its investment goal of more than $\$ 16$ million.

The SDWP project is expected to cost roughly $\$ 23.5$ million to build, but per the agreement with Basin Electric the exact amount will ultimately equal 6.48\% of Basin's total cost to build both the PrairieWinds SD1 and SDWP projects, and so will not be known with precision until construction has been completed. This $6.48 \%$ ratio represents SDWP's portion of the two combined projects - i.e., 7 out of 108 turbines total, or $10.5 \mathrm{MW}$ out of $162 \mathrm{MW}$ total. Similarly, during the operational phase, SDWP will pay Basin $6.48 \%$ of its total cost to operate

\footnotetext{
${ }^{16}$ Registering securities with the SEC can be a time-consuming and expensive process, potentially costing several hundred thousand dollars (primarily in legal fees) for an offering in the $\$ 10,000,000$ size range (Bolinger et. al 2004).
} 
and maintain both projects. Divvying up construction and operational costs proportionally rather than assigning SDWP the costs from 7 specific turbines helps protect SDWP from the moral hazard that might otherwise arise from Basin serving multiple roles as builder, operator, and power-offtaker of the 10.5 MW SDWP project. ${ }^{17}$

All of the electricity and RECs from the SDWP project will be sold to Basin under a 20-year power purchase agreement ("PPA") at a price that starts at \$43/MWh and escalates at 1.5\% per year (Sershen 2010). If exercised, a buyout option at the end of 6.5 years (described below) would terminate this contract early. While SDWP's construction and operating costs are calculated proportionally (as described in the previous paragraph), power sales will, in contrast, be based on the generation from seven specific turbines. In this case, however, the moral hazard of having Basin serve as both operator and offtaker is less obvious (presuming that Basin desires to maximize its wind generation), and is further reduced by the likelihood that Basin may eventually own these seven turbines itself.

Table 1 provides details of the offering, which consisted of three different investment options, each requiring a minimum (and incremental) investment of $\$ 15,000$ but featuring varying proportions of equity and debt. Class A consists mostly of debt (95\%), and is therefore wellsuited to those investors who do not have other sources of passive income against which to offset passive depreciation losses. Class B is also mostly debt (90\%), whereas Class C is mostly equity (95\%), and is therefore well-suited to those investors who are able to efficiently use passive depreciation losses. Reflecting the relative difficulty of finding investors with tax appetite, Class A sold out in just two weeks, followed by Class B in roughly 4 weeks, and finally Class C in eight weeks.

Table 1. South Dakota Wind Partners Intrastate Offering Details

\begin{tabular}{|c|c|c|c|c|}
\hline $\begin{array}{l}\text { Investment } \\
\text { Option }\end{array}$ & $\begin{array}{l}\text { Minimum } \\
\text { Investment }\end{array}$ & $\begin{array}{l}\text { Equity Portion } \\
\text { (and \# of shares) }\end{array}$ & $\begin{array}{l}\text { 6.5-Year Note Portion } \\
\text { (and interest rate) }\end{array}$ & $\begin{array}{l}\text { Total Amount Raised } \\
\text { (and time to raise) }\end{array}$ \\
\hline Class A & $\$ 15,000$ & $\$ 750$ (1 share) & $\$ 14,250(7.00 \%)$ & $\$ 7$ million ( $\sim 2$ weeks) \\
\hline Class B & $\$ 15,000$ & $\$ 1,500$ (2 shares) & $\$ 13,500(6.75 \%)$ & $\$ 4.5$ million ( $\sim 4$ weeks) \\
\hline Class C & $\$ 15,000$ & $\$ 14,250$ (19 shares) & $\$ 750(5.50 \%)$ & $\$ 5.3$ million ( $~ 8$ weeks) \\
\hline & Total: & $\$ 5.8$ million & \$11 million & \$16.8 million in $\sim 8$ weeks \\
\hline
\end{tabular}

In all three options, debt takes the form of a 6.5-year note whose interest rate is in direct proportion to the amount of leverage at stake: the Class A note earns the highest interest rate (7.0\%) whereas the Class C note earns the lowest (5.5\%). ${ }^{18}$ This sliding scale is in recognition of the fact that most of a Class A investor's return will come from the note, whereas most of a Class $\mathrm{C}$ investor's return will come from equity (i.e., the note's interest rate is less important to the overall return of a Class $\mathrm{C}$ investor).

The note is limited to just 6.5 years because the agreement with Basin includes a project purchase/sale option that can be exercised by either Basin or SDWP, respectively, at the end of

\footnotetext{
${ }^{17}$ In other words, allocating SDWP's construction and operating costs to its seven specific turbines rather than proportionally might have reduced Basin's incentive to efficiently construct and operate the SDWP project.

${ }^{18}$ A representative of Val-Add Services, which largely conducted the offering on behalf of SDWP, noted that in retrospect they probably could have offered lower interest rates, given that they had to turn away many Class A investors (Sershen 2010).
} 
6.5 years - i.e., a time-period that exceeds both the Section 1603 grant's 5-year recapture period as well as the 5-year MACRS depreciation schedule (which actually extends into the project's sixth year). Current expectations are that both Basin and SDWP will want to exercise this option and transfer project ownership based on a formula-based price, but if for some reason neither party ends up exercising the option, SDWP will need to refinance the note at that time.

In total, the offering raised roughly $\$ 16.8$ million from more than 600 investors who are mostly individuals (as opposed to businesses), and mostly members of one of the four founding organizations. The average investment size is around $\$ 27,000$. The resulting overall mix of equity and debt is $\$ 5.8$ million and $\$ 11$ million, respectively. The remainder of expected project costs - roughly $\$ 6.7$ million - will ultimately come from the Section 1603 cash grant, leaving overall project leverage at roughly $50 \%$ (considering the grant as equity). Because the grant will not be paid until the project is operational, however, SDWP has taken out a similar-sized bridge loan from CoBank in the interim. ${ }^{19}$

\section{Significance}

The significance of the SDWP project is principally that it may be the first wind project to be built that has been financed by an intrastate offering, and is almost certainly the first offering of both equity and debt. National Wind - a well-known community wind developer - has conducted intrastate offerings in various states in the past, but few (if any) of these projects have yet been built, and its offerings typically consist of high-risk early-stage equity that is used primarily for development purposes, rather than for constructing projects (National Wind generally seeks third-party tax equity investors to provide construction equity).

This comparison highlights the importance of the Section 1603 cash grant to the SDWP project. By replacing the PTC with cash, the Section 1603 grant facilitated individual investment by reducing the need for tax appetite. Investors who could not have efficiently absorbed both the PTC and depreciation losses may nevertheless be able to absorb just the depreciation losses. And for those investors who simply can't use even depreciation, SDWP's unique offering of various combinations of debt and equity (including one option with just $5 \%$ equity) ensures that most investors can find a suitable investment to fit their individual tax appetites. The cash grant also reduced the minimum required holding period from 10 years (for the PTC) to 6.5 years for the SDWP project - a term that may be more palatable to many community wind investors.

Piggybacking on the larger PrairieWinds SD1 project reduces project costs (SDWP benefits from the economies of scale realized by the larger PrairieWinds project), transaction costs, project risk (construction, operations, and offtake risk), and the development timeline. The SDWP project was under construction within a year of being conceived - much more quickly than other projects profiled in this report. Granted, Basin had presumably been developing PrairieWinds SD1 - and therefore by extension SDWP - for longer than a year, but the broader point is that the risk to SDWP investors was clearly reduced by piggybacking on this larger Basin effort.

\footnotetext{
${ }^{19}$ Nick Sershen of Val-Add Service Corporation notes that if they could do it over again, they would have raised the \$6.7 million bridge loan through the offering itself (e.g., as a 6-month note), rather than by going to CoBank (Sershen 2010). Closing the construction loan with CoBank has proven to be more difficult and expensive than envisioned.
} 
Even though it was reportedly not a motivating factor for the SDWP project, this sort of investment offering - conceived of and facilitated by an electric cooperative - represents a creative way to sidestep the "all-requirements" issue that often stands in the way of cooperatives developing their own wind projects. Specifically, many distribution cooperatives (as well as some generation and transmission cooperatives like East River) are supplied with power from other cooperatives under what are known as "all-requirements" or "full-requirements" contracts, which may prohibit the distribution cooperatives from developing their own power sources. The SDWP model represents a way in which a cooperative can respond to its members' interest in developing wind power without infringing upon its all-requirements contracts - i.e., by facilitating a project in which its members can invest directly, rather than indirectly through the cooperative.

Of course, SDWP's particular situation is perhaps somewhat unique - e.g., the impending construction of the large PrairieWinds SD1 project and Basin's multiple roles as developer, owner, operator, and power offtaker; the extra turbine permits that were not being utilized; and the strong existing relationship between East River and Basin. ${ }^{20}$ That said, the basic model employed by SDWP - i.e., opening a small portion of a larger project for community investment - is one that could be replicated more broadly, even outside of the cooperative world, and potentially to the advantage of larger "commercial” wind developers. For example, a commercial wind power developer of a larger project could potentially help to shore up local support for that project (and not just from among those landowners who will be hosting turbines and therefore receiving lease payments) by allowing all local residents to invest in some portion of the project. Of course, under an intrastate offering, "local” means statewide, and developers should be mindful of each state's securities regulations before proceeding down this path.

Finally, as do other projects profiled in this report, this project highlights the importance of working with capable partners. The SDWP project could not have happened without Basin's consent, and would have been more complicated if Basin were not able to build and operate the project and buy its power. Likewise, the intrastate offering may not have gone as smoothly or been as successful without the assistance of Val-Add Service Corporation, which has experience with similar offerings to finance ethanol plants.

\subsection{Coastal Energy Project, LLC}

\section{Background}

The Coastal Energy Project is a 6 MW wind project, consisting of four GE 1.5 MW turbines, located in Grayland, Washington. The project's sponsor is the Coastal Community Action Program (“CCAP”), a community service provider that serves low-income, elderly, and disabled residents of Pacific and Grays Harbor counties, Washington. Income generated by the project

\footnotetext{
${ }^{20}$ Reportedly one important factor that motivated Basin to work with the SDWP project was the fact that "their owners are our owners" (Sershen 2010) - a general nod to the cooperative model in which a cooperative is owned by its members, and more specifically to the inter-related ownership of East River and Basin (the latter is partly owned by the former).
} 
over its lifetime will help to fund the wide range of social programs that CCAP offers. For this reason, Craig Dublanko, the project's champion at CCAP, has described the project as "a social service project that happens to involve wind energy” (Hill 2010).

The project has been in the works (if not actively in development) in one form or another since 2000. Pre-development work and feasibility studies were funded by two Residential Energy Assistance Challenge ("REACh") grants, which are a part of the Low-Income Home Energy Assistance Program ("LIHEAP”) managed by the U.S. Department of Health and Human Services. A significantly larger infusion of support came in mid-2007, when the state of Washington provided the project with a \$5 million grant. In September 2008, just as the market for wind turbines was imploding as a result of the unfolding financial crisis, GE Energy extended a contract to CCAP for four 1.5 MW turbines. Subsequently, the local utility - the Grays Harbor Public Utility District - agreed in April 2009 to buy power and RECs from the project over a 20year period, at a price that starts at $\$ 75 / \mathrm{MWh}$ and escalates over time. Financing closed in December 2009, and by the end of June 2010, the project was operational.

\section{Financing Details}

The Coastal Energy Project is the first wind project in the U.S. to take advantage of New Markets Tax Credits ("NMTCs"), as well as the first to be financed through an "inverted" or "pass-through" lease structure. As noted earlier in Section 3, NMTCs are intended to promote private investment in low-income communities by providing an investment tax credit equal to $39 \%$ spread over a period of seven years (5\% in each of the first three years, and $6 \%$ in each of the last four). The NMTCs are triggered by, and based upon, a Qualified Equity Investment (“QEI”) - which itself can be leveraged - in a community development entity (“CDE”), which is an intermediary that has previously received an allocation of NMTCs from the U.S. Treasury. The CDE, in turn, invests substantially all of the QEI in a qualifying low-income business (or project company). ${ }^{21}$ The CDE investment in the business or project can take the form of either debt or equity.

Meanwhile, an inverted lease is, as its name suggests, essentially just the opposite of a normal lease. In a reversal of roles, the project sponsor or developer plays the role of lessor, while the tax equity investor serves as lessee. As lessee, the tax equity investor sells the power generated by the project and pays most of the resulting revenue to the lessor in the form of rent (i.e., lease payments). The expensing of these rent payments roughly approximates the value of depreciation deductions, which the tax equity investor has forfeited by serving as lessee. The developer/lessor, in turn, uses the depreciation deductions to shelter much of the rent revenue, and also elects to pass through the ITC or cash grant to the lessee (Martin et al. 2009). Developers may like this structure because, as lessor, they retain ownership at the end of the lease term, and so do not need to buy out the tax equity investor at that time. The fact that the project sponsor retains majority ownership throughout the lease is also important from a New Markets Tax Credit perspective (Grappone 2010).

\footnotetext{
${ }^{21}$ Eligible businesses are those that meet the requirements set forth for "qualifying active low-income community businesses” in the NMTC statute, available here: http://www.cdfifund.gov/docs/2000_nmtc_statute.pdf.
} 
The structure used for the Coastal Energy Project involves not just one, but two tax equity investors investing in two different CDEs. Initially, Wells Fargo placed an \$8.18 million leveraged investment in Shorebank Enterprise Cascadia (a CDE), with the leverage coming from a loan of the $\$ 5$ million grant that CCAP had earlier received from Washington state. In turn, Shorebank provided a similarly sized ( $\sim 8$ million) low-interest loan to the special-purpose project company, Coastal Energy Project, LLC. Wells Fargo will benefit from nearly \$3.2 million in NMTCs generated by its \$8.18 million investment in Shorebank Enterprise Cascadia, and will also eventually recoup its principal of $\sim$ \$3.18 million (again, the additional \$5 million came from the Washington state grant) plus interest. ${ }^{22}$

The second NMTC investment came from US Bancorp, which invested \$6.86 million in United Fund Advisors’ National Community Fund I, LLC (a second CDE). In turn, National Community Fund I set up the pass-through lease structure, injecting equity into Coastal Energy Project, LLC. US Bancorp receives not only the NMTCs (from its qualifying investment in National Community Fund I), but also the Section 1603 grant, which Coastal Energy Project passes through to it via the inverted lease structure, and cash revenue in excess of lease payments.

At the end of the NMTC period - seven years - both CDEs and tax equity investors will exit the project, which will thereafter be owned solely by CCAP.

\section{Significance}

Although this financial structure is clearly innovative, its significance - in terms of likely impact on the future of the community wind market - is harder to judge. On the one hand, NMTCs seem ideally suited to community wind projects, both in scope (i.e., projects serving underprivileged communities, many of which are located in rural, windy census tracts) and size (CDE's prefer relatively small investments, rarely exceeding \$10 million). NMTCs also provide quite a bit of value and appear to be compatible with other federal incentives (including the PTC) without triggering “double-dipping” or "haircut” penalties.

On the other hand, the Coastal Energy Project demonstrates how complex it can be to structure NMTCs. Transaction costs for this structure were extremely high (Dublanko 2010), and some tax counsel are not entirely comfortable with the tax risk surrounding certain inverted lease structures (Martin et al. 2009). Replication of this particular structure also depends not only on the New Markets program being extended (allocations are currently authorized through 2011), but also on having continued access to the ITC or Section 1603 grant, since leasing is not permissible under the PTC. In addition, not all wind projects will meet the requirements for a "qualifying active low-income community business," and those that do may not be able to find a CDE that has received an allocation of NMTCs. This combination of high complexity, high transaction costs, and potentially limited replicability likely renders this structure somewhat-lessappropriate for community wind projects than some of the others described in this report.

\footnotetext{
${ }^{22}$ The aggregate NMTCs that will be generated by Wells Fargo's QEI amount to nearly $\$ 3.2$ million, which roughly approximates the size of its equity investment (which, again, was leveraged by the $\$ 5$ million grant from Washington state).
} 


\subsection{PáTu Wind Farm, LLC}

\section{Background}

In Sherman County, Oregon, surrounded by $850 \mathrm{MW}$ of commercial wind power from the Klondike and Biglow Canyon wind projects, is the $9 \mathrm{MW}$ PáTu community wind project. $^{23}$ Developed by brothers Ormand and Jeff Hilderbrand on land that their family has been farming for more than a century, the PáTu wind project consists of six GE 1.5 MW turbines, and achieved commercial operations in early December 2010.

\section{Financing Details}

Securing financing for the PáTu project was a long and tortuous journey. The Hilderbrand brothers - through the special purpose development entity Oregon Trail Wind Farm, LLC that they formed in 2005 - had in early 2008 partnered with MMA Renewable Ventures, a wellknown tax equity arranger for large commercial photovoltaic projects in California and elsewhere (PáTu was to be MMA's first wind project). The resulting partnership, known as PáTu Wind Farm, LLC, was in the midst of negotiations with institutional tax equity investors over a PTC monetization when the financial crisis broke in late 2008.

The crisis had two immediate impacts on the PáTu project. First, the tax equity investors walked away from the project. Second, MMA Renewable Ventures - which was a subsidiary of realestate finance company Municipal Mortgage \& Equity (MuniMae) - was sold to Spanish solar power producer Fotowatio (in March 2009). Fotowatio, in turn, had little appetite for wind projects, instead choosing to focus on its core capabilities by developing MMA's solar project pipeline.

As a result, Oregon Trail Wind Farm LLC was back to square one - almost. It still retained several valuable financial assets from state-level programs, most notably a pre-certified application for Oregon's Business Energy Tax Credit (BETC). At that time, the BETC provided a generous $50 \%$ state investment tax credit, taken either over five years (at $10 \%$ per year) as a state income tax credit, or upon achieving commercial operations as an up-front, lump-sum, discounted "pass-through" cash payment. ${ }^{24}$ Subsequent changes to the BETC would make it less valuable to wind projects, but the PáTu project was grandfathered against these changes by having been pre-certified under the old rules.

\footnotetext{
${ }^{23}$ In the language of the local Native American tribes, PáTu is the name given to Mount Adams, which lies to the northwest of the project. In a more generic sense, it can also refer to "snowfields" (e.g., the snow-covered slopes of Mount Adams) or "the source of all life" (e.g., the water from the melting snowfields provides life to the area). ${ }^{24}$ The BETC pass-through option allows a project owner to transfer its tax credit to a pass-through partner in return for a discounted lump-sum cash payment upon the project's completion. At the time when PáTu obtained its BETC pre-certification, renewable energy projects with eligible costs greater than $\$ 20,000$ received a pass-through rate of $33.5 \%$ (discounted from the 50\% BETC to reflect the time value of money and other factors). Although the Oregon Department of Energy, which administers the program, may assist a project owner in the BETC pass-through process, ultimately it is the responsibility of the project owner to find a pass-through partner for the project. For more information on the BETC program, see http://egov.oregon.gov/ENERGY/CONS/BUS/BETC.shtml.
} 
Oregon's Energy Loan Program, meanwhile, provides long-term financing for renewable energy projects at attractive rates. The state issues bonds to fund the loans, and passes through the low interest rate (based on the State of Oregon's credit), plus a fee, to the borrower. Through this program, the PáTu wind project secured an initial \$8 million and then a subsequent \$4 million (for a total of $\$ 12$ million) 20-year term loan at an interest rate that will likely be priced at around $6.25 \%-6.5 \%$ once the loan is drawn down. ${ }^{25}$ This will be the Energy Loan Program's first loan to a utility-scale wind project.

The project had also secured a 20-year fixed-price PPA with Portland General Electric under its 2009 standard contract for projects less than $10 \mathrm{MW}$. Notably, this standard contract is for energy only; the PáTu project will retain the associated renewable energy certificates (RECs).

With RECs in hand, the project also applied for an incentive from the Energy Trust of Oregon the non-profit that administers Oregon's ratepayer-funded renewable energy and energy efficiency fund. In late-July 2009, the Energy Trust awarded a \$1.2 million incentive (to be paid over 5 years and representing 58\% of the above-market cost of the project), to be repaid by granting 58\% of the annual RECs to the Energy Trust. Ultimately, however, the PáTu project declined this Energy Trust incentive on the presumption that it could do better by retaining all of its RECs for future sale.

To recap, at the end of 2009 (and after several false starts), the PáTu project had in hand a 20year PPA (though not yet executed) with retained RECs, a 20-year term loan for roughly $40 \%$ of the projected $\$ 23$ million cost of the project, a pre-certified BETC application worth nearly onequarter of project costs, and the prospect of a Section 1603 cash grant worth almost 30\% of project costs. ${ }^{26}$ None of the capital from these sources, however, would begin to flow in until the project was up and running. Getting to that point remained a serious challenge, as construction financing - both equity and debt - was still needed.

The equity piece - \$5.685 million in preferred equity financing - came from Vert Investment Group and two wealthy families (one an acquaintance of the Hilderbrand's and the other Vert's relationship; only one of these families will be able to use federal depreciation losses). The preferred equity partners start with a 99\% interest in gross income and a 100\% interest in cash distributions (per the safe harbor provided by the IRS Revenue Procedure 2007-65), both of which flip down to $90 \%$ once the investors have earned back their principal. A second flip down to $50 \%$ occurs once the preferred equity investors have reached their targeted internal rate of return (IRR). At the end of the project's fifth year of operations, Oregon Trail Wind Farm, LLC (i.e., the Hilderbrand brothers) have an option - good for one year - to buy out the preferred equity investors, and hope to do so.

\footnotetext{
${ }^{25}$ Although the SELP loan is for $\$ 12$ million initially, the Oregon Department of Energy (i.e., the loan administrator) requires $\$ 2$ million to be paid back once the project receives the BETC pass-through payment. As such, in terms of permanent financing, it is considered to be a $\$ 10$ million term loan. The interest rate had not yet been locked in at the time of writing.

${ }^{26}$ The exact amounts of both the Section 1603 grant and the BETC pass-through payment will not be known with certainty until construction is complete and the Section 1603 grant has actually been awarded. Calculating the Section 1603 grant basis for this project has been complicated by pre-existing expenses having to do with the aborted partnership with MMA Renewable Ventures. Meanwhile, the Section 1603 grant amount must be subtracted from the eligible BETC basis before calculating the BETC pass-through payment.
} 
The final piece of the puzzle - a construction loan - ultimately (after failed attempts at several local banks) came from CoBank, a cooperative bank that is part of the Farm Credit System established by the U.S. Congress in 1916. CoBank typically lends to rural cooperatives or projects serving rural areas, rather than to generators selling power to investor-owned utilities. As mentioned earlier in Section 3, however, a provision in the 2008 Farm Bill (Section 6108) expanded the USDA's (and, by extension, CoBank’s) lending authority - for renewable generators only - to projects that serve either rural or non-rural areas. Using its newly expanded authority, and comforted by the multiple sources of capital (term loan, BETC pass-through payment, and Section 1603 grant) that would flow into the project post-construction, CoBank agreed to lend the PáTu wind project \$16.5 million in construction financing (nearly 75\% leverage).

\section{Significance}

Although the financial structure used for this project is somewhat-less-innovative than others profiled in this report (i.e., this is essentially still a partnership flip structure), the financial significance of this project is that it exemplifies the resourcefulness or "bootstrapping" that community wind projects must often employ in order to piece together a suitable financial package. The PáTu project is fortunate to be located in a state that has several different types of programs that support community wind projects. At one time or another, the project sought funding from all of these programs - the BETC, the Energy Loan Program, and the Energy Trust of Oregon. Although it ultimately declined the Energy Trust funding, these state-level incentives were the sustenance that kept the project going when the initial federal tax monetization strategy collapsed.

Over the course of its development, the project also benefited from several changes to federal policy. Section 6108 of the 2008 Farm Bill expanded CoBank's lending authority to renewable generation projects like PáTu that don't only benefit rural entities. More importantly, the February 2009 passage of the Recovery Act provided much-needed relief during the project's darkest hours. Most notably, the Section 1603 cash grant allowed the project to recover from the collapse of its partnership with MMA Renewable Ventures and turn to somewhatunconventional equity investors who were not primarily motivated by tax credits. In addition, the Recovery Act eliminated the "subsidized energy financing" haircut for the $30 \%$ ITC and the Section 1603 cash grant, but not for the PTC (Bolinger 2010). Though it is unclear whether or not Oregon's Energy Loan Program would be considered by the IRS to be "subsidized energy financing” (this question has never been tested, as this is the Program's first loan to a utilityscale wind project), the fact that the PáTu project plans to elect the Section 1603 cash grant rather than the PTC renders this potential uncertainty moot.

Finally, this project also exemplifies the benefit of partnering with experienced financial advisors. Oregon Trail Wind Farm, LLC originally turned to MMA Renewable Ventures for assistance with pulling together a tax equity monetization. Following the financial crisis and MMA's exit from the project, the Hilderbrand's eventually brought in Vert Investment Group, LLC to help negotiate the PPA agreement, the turbine supply agreement, and the interconnection agreement, and to arrange the ultimate financial package. In announcing the closing of the 
financial package, Ormand Hildebrand of Oregon Trail Wind Farm, LLC was quoted as saying "There would have been doubt without Vert. I could have succeeded but it would have taken longer. It would have been much more time-consuming and I probably would have made a lot more false starts." This testimonial to the value that experienced financial advisors can bring to a project is particularly germane given that it is grounded in the experience of someone who weathered several false starts during the more-than-five years that the PáTu project was under development. 


\section{Common Observations and Lessons Learned}

This section concludes the report by attempting to distill the collective experiences of the five community wind projects profiled in Section 4 into a number of common observations or lessons learned regarding the development and financing process - in particular those observations or lessons that might be useful to other community wind projects and stakeholders.

\subsection{The Recovery Act Has Been Critically Important to Most of These Projects}

The Recovery Act, and in particular the Section 1603 grant, has been critically important to most of these projects. By reducing the need for tax equity, the Section 1603 grant enabled South Dakota Wind Partners to find sufficient equity capital among individual investors (presumably some of whom would not have been able to absorb passive depreciation losses in addition to a PTC or an ITC), and simplified the financing of the PáTu project. The ability to pursue lease financing under the ITC or grant was obviously critical to the success of the Ridgewind and Coastal Energy projects. Finally, the Recovery Act's elimination of the ITC's (and grant's) double-dipping penalties for subsidized energy financing has eliminated the risk that PáTu's term loan from Oregon’s Energy Loan Program might be considered subsidized financing.

Although the deadline to qualify for the grant has been extended through 2011, wind projects must still be online by the end of 2012 to receive the grant or ITC in lieu of the PTC (which is also currently slated to expire at the end of 2012). Efforts to extend one or more of these incentives will no doubt be underway throughout 2011 and 2012, but at present the window of opportunity to take advantage of the grant in particular is relatively short.

\subsection{Don't Overlook The Need for Seed Capital}

The trade and general press tend to focus on construction and permanent financing, but most of the projects reviewed in this report had spent upwards of half a million dollars in seed capital before even getting to the construction financing stage. Raising this amount of seed capital much of which is spent on relatively fixed development costs - can be a significant hurdle for community wind projects, and in particular smaller community wind projects. Fox Islands Wind raised $\$ 350,000$ by issuing contingent promissory notes (and beyond that amount operated on credit until the equity investment and construction loan came in (Baker 2010)). South Dakota Wind Partners utilized $\$ 80,000$ in grants from its four founding members, along with an additional \$300,000 investment from other board members, to flesh out the offering. The Coastal Energy Project funded some of its early-stage development work out of two Residential Energy Assistance Challenge (REACh) grants, and later received a \$5 million grant from Washington state. 


\subsection{Piggybacking on Nearby Projects Can Help Ease the Burden}

South Dakota Wind Partners provides the most obvious example of the benefits of piggybacking on adjacent projects. The PáTu project, however, has also benefited from shared infrastructure and local knowledge from nearby commercial wind development.

\subsection{Partnering With Experienced Professionals Can Create Opportunities}

Although the projects profiled in this report are modest in size, they are nevertheless complex undertakings involving novel financing structures, which in many cases represent industry firsts. Each of these projects relied on partnerships with experienced professionals to provide access to a range of opportunities and to facilitate the project's successful development. For example, EOS Ventures helped the Fox Islands Wind project procure turbines from GE and deliver them to the island site. Miracol Energy - a financial consultancy with ties to the tax equity market helped the Ridgewind project get its foot in the door at Union Bank and advised PRC on the sale/leaseback financing. South Dakota Wind Partners is not only heavily dependent on Basin Electric, but also Val-Add Service Corporation, which assisted the project's board of directors in conducting the intrastate offering and will help administer the project. Chinook Wind did most of the development work for the Coastal Energy Project, and several tax lawyers and accountants were critical to working out the financing details. Finally, after several false starts, the PáTu project brought in Vert Investment Group to piece together its final financing package.

\subsection{Consider the RUS As a Source of Debt}

Although it has historically provided loans primarily to rural electric cooperatives, the USDA's Rural Utility Service is able to provide non-recourse debt financing to standalone wind projects on a project finance basis; the Fox Islands Wind project stands as proof of this. Moreover, after having climbed the learning curve with Fox Islands Wind, and with expanded authority from Section 6108 of the 2008 Farm Bill, the RUS is interested in expanding its portfolio of wind project loans. ${ }^{27}$ The loan instrument used for this purpose to date - an "FFB Guaranteed" loan is beneficial to wind not just because of the low interest rate (just 12.5 basis points above the corresponding Treasury yield), but also because the IRS does not consider government loan guarantees to be "subsidized energy financing." As such, these RUS loans could be used in conjunction with the PTC (if/when access to the ITC/grant expires) without triggering a PTC haircut.

\footnotetext{
${ }^{27}$ A second wind project built in 2010 - the 12 MW Greensburg wind project in Kansas - was awarded a \$17.4 million RUS loan in October 2009. However, the project's owner - John Deere Wind - ultimately declined the loan when John Deere's renewable energy unit was sold to Exelon.
} 


\subsection{Don't Overlook New Markets Tax Credits}

Given their typically small size, community wind projects should generally strive for greater simplicity rather than increased complexity in financing structures. The realities of the market, however, often require that complex financing structures be employed in order to maximize available incentives. For this reason, NMTCs are worth keeping in mind should an appropriate opportunity present itself. Although NMTCs can be complex to structure, they do provide quite a bit of value (on a present value basis, effectively the equivalent of a second ITC), which in some cases could justify the high transaction costs of pulling together an NMTC deal.

\subsection{Be Prepared for a Long Haul}

Developing a wind project can be a drawn-out process, requiring patience, tenacity, and adequate development capital. At least three of the five projects reviewed in this report have endured development cycles of five years or longer - despite being relatively modest in size. The PáTu project, in particular, demonstrates how it is easy to become a victim of circumstance with respect to global events outside of the project's control. South Dakota Wind Partners, in contrast, was starting construction a little more than a year after first being conceived (not including the time that Basin Electric no doubt put into developing the larger project), once again demonstrating the benefits of piggybacking on nearby development.

\subsection{The Shift from Construction to Commercial Operations Can Bring New Challenges}

Although this report has focused primarily on project financing, the challenges do not necessarily end once a project has been financed and built. Several of the projects reviewed in this report have recently shifted from the construction phase to the operational phase, and are now facing operational challenges. For example, the PáTu project is now grappling with issues related to integrating its power into the Bonneville Power Administration's grid. The Coastal Energy Project is also dealing with integration issues - voltage on the local grid is too high when all four turbines are operating (Grays Harbor PUD 2010). The Fox Islands Wind project has been working with island residents over the past year regarding noise complaints, experimenting with different operational strategies to try and minimize the impact on nearby residents. And, finally, Ridgewind Power Partners, LLC will essentially conduct a partial refinancing (of the specialpurpose project company, not the project's hard assets) after the Ridgewind project achieves commercial operations, by implementing PRC’s Minnesota Windshare program. 


\section{References}

Altenberg, Joaquin (Vert Investment Group). 2010. Personal communication by phone: October 15, 2010.

American Wind Energy Association (AWEA). 2010. Community Wind Policy Position. http://www.awea.org/documents/2010_Community_Wind_Policy_Position_Paper.pdf

Baker, George (Fox Islands Wind, LLC). Personal communication by phone: October 22, 2010.

Bolinger, Mark. 2010. Revealing the Hidden Value that the Federal Investment Tax Credit and Treasury Cash Grant Provide to Community Wind Projects. LBNL-2909E. Berkeley, Calif.: Lawrence Berkeley National Laboratory. http://eetd.lbl.gov/EA/EMP/reports/lbnl-2909e.pdf

Bolinger, Mark, Matt Karcher. 2009. A Review of Feasible Financing Structures for Community Wind Projects in Pennsylvania. Prepared for the Saint Francis University Renewable Energy Center, September 2009. http://www.francis.edu/uploadedFiles/Renewable_Energy_\%28new\%29/FinancingStructuresCommunityWind.pdf

Bolinger, Mark, John Harper, Matt Karcher. 2009. “A Review of Wind Project Financing Structures in the USA.” Wind Energy. Vol 12, Issue 3, April 2009, pp. 295-309.

Bolinger, Mark and Ryan Wiser. 2006. “A Comparative Analysis of Business Structures Suitable for Farmer-Owned Wind Power Projects in the United States.” Energy Policy. Vol 34, Issue 14, September 2006, pp. 1750-1761.

Bolinger, Mark, Ryan Wiser, Tom Wind, Dan Juhl, Robert Grace. 2004. A Comparative Analysis of Community Wind Power Development Options in Oregon. Prepared for The Energy Trust of Oregon, July 2004.

Dublanko, Craig. 2010. Remarks made during the "Case Studies and Success Stories” panel at AWEA’s Small and Community Wind Conference \& Exhibition in Portland, Oregon on December 8, 2010.

Grappone, Tony. 2010. “Opportunities for Renewable Energy Projects to Pair 1603 Grants with NMTCs” Novogradac Journal of Tax Credits. Volume I, Issue III, March 2010.

Grays Harbor PUD. 2010. Minutes from Special Meeting of the Commission of Public Utility District No. 1 of Grays Harbor County, November 1, 2010.

Hilderbrand, Ormand (Oregon Trail Wind Farm, LLC). 2010. Personal communication by phone: October 19, 2009.

Hill, Jennifer. 2010. “Community Service Organization Harnesses Wind Energy.” Novogradac Journal of Tax Credits. Volume I, Issue IV, April 2010. 
Martin, Keith. 2008. “Calculating How Much Tax Equity Can Be Raised.” Chadbourne \& Parke LLP’s Project Finance Newswire, June 2008, pp. 18-26.

Martin, Keith, Ken Hansen, John Marciano, Eli Katz. 2009. Financing Renewable Energy Projects After the Stimulus. Chadbourne \& Parke LLP, Special Update, February 2009.

National Renewable Energy Laboratory (NREL). 2010. "Financing Solar Installations with New Markets Tax Credits: Denver, Colorado.” Fact Sheet Series on Financing Renewable Energy Projects, NREL/FS-7A2-49056, September 2010. http://www.nrel.gov/docs/fy10osti/49056.pdf

Sershen, Nick (Val-Add Service Corporation). 2010. Personal communication by phone: October 12, 2010.

White, Paul (Project Resources Corporation). 2010. Personal communication by phone: October 22, 2010.

Wiser, Ryan and Mark Bolinger. 2010. 2009 Wind Technologies Market Report. LBNL-3716E. Berkeley, Calif.: Lawrence Berkeley National Laboratory. http://eetd.lbl.gov/EA/EMP/reports/lbnl-3716e.pdf 